\title{
WHAT HAS CHANGED \\ A new farewell to the working class?
}

\section{Vitor Araújo Filgueiras}

https://orcid.org/0000-0002-3284-9178

\section{Sávio Machado Cavalcante}

(D) https://orcid.org/0000-0002-8496-5357

(1) Professor da Universidade Federal da Bahia (UFBA), Salvador - BA, Brasil. E-mail: fvitor@ufba.br

(2) Professor da Universidade Estadual de Campinas (Unicamp), Campinas - SP, Brasil. E-mail: saviomc@unicamp.br

DOI: $10.1590 / 3510213 / 2020$

\section{Introduction}

This paper debates issues concerning the organization of work and production in the current context of capitalism, mainly work management, labor process and its implications on the regulation of labor. It aims to discuss the thesis according to which capitalist societies have been through a sharp shift in the nature of work relations, assuming that social and economic changes in work management and new technologies would have dissolved traditional forms of employment. Using the idea that self-employment, new forms of work or the precariat is growing, there is a relative consensus among many authors and institutions that the decline of wage labor is a feature or a trend of contemporary labor markets. This perspective has had an enor-

Artigo recebido em: 07/05/2018

Aprovado em: 05/09/2019 mous repercussion on labor studies in the last decades and has increasingly affected the regulation of labor around the globe.

We do not deny the emergence of changes in labor management by companies. However, we strongly disagree that these modifications have implied the reduction of wage labor or have made labor law unfeasible. To sustain and develop these central ideas, the main arguments presented here are:

1. Despite many claims to the contrary, wage work has grown all over the world according to aggregated data covering the last decades. Even in countries in which self-employment has increased in the last few years, there is no sustainable indicator showing a decline in wage work.

2. The majority of the so-called new forms of work are strategies adopted by companies to manage wage work, increasing flexibility (and 
precariousness) by denying the employment relation itself.

3. The growth or decline of real or disguised selfemployment is strongly linked to labor market performance and social regulation of labor.

4. The narrative we call the new "farewell to the working class", whether deliberately or unintended, has helped the strategy of capital to increase its power by making labor more precarious and workers less likely to confront exploitation. This is so because the thesis of the spread of new forms of work contributes to legitimize precarious forms of contracting and managing labor by presenting them as inexorable.

This paper shows some examples of how these supposed new work forms are in fact a strategy of capital to impose different ways of hiring workers ${ }^{1}$. One of the main capitalist procedures has been not to present themselves as employers, calling these workers by other names, such as "independent" producers, "partners", etc., or saying that companies are now organized upon "new ways of work", instead of hiring employees. Actually, this process has undermined chances of limiting labor exploitation, thus seeking many facilitations for accumulation, such as making collective actions less likely to occur, impairing labor rights, increasing management flexibility etc.

This process also encourages (and is encouraged by) the idea that class structure has changed, enabling the strengthening of debates over the socalled precariat, in one view, or the "grey zone" in the labor market, in another. Although these perspectives are politically different, they both claim that wage labor has been reduced, replaced by other types of work or even by other classes. Thus, in a conjuncture of a huge offensive of capital and the increasing subsumption of the working class by it, we are witnessing a new farewell to the working class ${ }^{2}$.

The new farewell to the working class is an expression inspired by Andre Gorz's and Ricardo Antunes' books, respectively "Farewell to the proletariat" (1982) and "Farewell to work?" (1995). Like the first farewell, the current process has theoretical and empirical problems, but not of the same kind. We believe it is misleading the way in which some authors and institutions address the changes (or supposed changes) in the world of work, referring to both theoretical and political problems.

This paper is based on empirical data from around the world but focuses on the cases of the Brazilian and British labor markets. Although these countries have distinct productive structures and differences in their labor markets and social regulations, they were chosen as a way to analyze general trends that impact both central and peripheral countries.

We have carried out several case studies over some of the most famous "new forms of work" in order to analyze their content and how they differ from traditional employment in terms of subordination to capital.

From a methodological point of view, we used the following resources: we present data organized on a global scale regarding the participation of wage labor in the general set of economically active and inactive people. Afterwards, we identify cases representative of "new forms of work" in different economic sectors in Brazil and the United Kingdom in order to describe the formats and consequences of contracts in these countries. These are representative cases of sectors and companies that have achieved prominence on a global scale and are also indicated as likely trends for the labor market as a whole. Therefore, the analysis seeks to articulate a larger dimension of the process with the description of typical situations in which the object of this discussion can be analyzed in its concrete expression. In this sense, we prioritize the qualitative description of the specific cases.

Besides this introduction, there are four sections in this paper: initially, the first and the new farewell to work are presented. Secondly, the empirical consistency of the new farewell is tested; data is also used to link labor market performance and regulation and wage employment incidence. Finally, there is a brief discussion to emphasize the role played by literature and its political consequences in terms of labor regulation. 


\section{The first and the new farewell to the working class}

\section{The first farewell to the working class}

We give the name first farewell to the working class to formulations that, in the 1980s, sought to reposition concepts, categories and methods of analysis that focused on employment and labor relations in capitalist societies. Addressing the social theory most related to the studies of labor relations, we have the works of André Gorz, specifically Adieux au Prolétariat (1980), Le chemins du Paradis, L'agonie du capital (1983) and Métamorphoses du travail. Quete du sens: critique de la raison économique (1988), and the set of texts of Claus Offe organized in Arbeitsgesellshaft: Strukturprobleme und Zukunftsperspektiven (1984).

The main approach of these works referred to a set of technical, organizational and value changes that would have rendered the conceptual models built in and for a "society of work" an anachronism.

Indeed, the longing for a theoretical implosion of these models begins much earlier. In her foreword to The Human Condition (1958), Hannah Arendt justified the need for an alternative to what she called the "theoretical glorification of work" as a form of refusal to technical and instrumental rationality that nullifies the capacity to construct meaningful intersubjective discourse in the political sphere. The author, whose influence on André Gorz is remarkable, anchored her proposal in what she called a "threatening event":

This is the advent of autonomation, which in a few decades probably will empty the factories and liberate mankind from its oldest and most natural burden, the burden of laboring and the bondage to necessity. (...) What we are confronted with is the prospect of a society of laborers without labor, that is, without the only activity left to them. Surely, nothing could be worse (Arendt, 1958, p. 4-5).

It was precisely this "society of laborers without labor" that seemed to take place historically in the last decades of the twentieth century due to the impact of the microelectronic revolution which, for Gorz (1983), "inaugurates the age of abolition of work" in two senses. First, the quantity of labor diminishes to the point of "becoming marginal in most material productions and organizational activities"; second, the "face-to-face of the worker with matter" is undone, which is now transformed into a completely mediated way through the technique. Arendt's prediction would be proving itself even more appropriate.

It is important to observe that Gorz's theses critically referred to three theoretical traditions: Keynesianism, because it would be "impossible to restore full employment" (1982, p.3); Marxism, in the sense of the collective or self-managed appropriation of the productive forces, as well as the desire to eliminate alienation or heteronomy at work, which is impossible due to the impersonal character of the functional power of technical production; and liberalism, because the solution to this situation could not be based on the imposition of economic rationality in the service sector, which seemed to compensate for the loss of jobs in industry. Putting aside the refusal of these three theoretical currents, Gorz offers a precise normative dimension of his theses, according to which, having a job may not be the criterion of social integration, that is, the only link leading to citizenship. Basic income policy appears as the only progressive trend.

In his approach, there is a causal structure that, put in technical terms, operates in two main senses. First, as the objective basis of the argument, the author identifies the impossibility of constructing an inclusive social project based on work because human labor would no longer be the main source of all wealth (Gorz, 1982) or it would no longer be the main productive force (Gorz, 1989). Secondly, it is mainly the technique what provokes the "segmentation and disintegration of the working class" (Gorz, 1989, p. 66).

According to Gorz, the combination of work's loss of relevance in terms of wealth generation and the preservation of capitalist economic rationality results in a structural fragmentation of the working class, such as follows: a) a privileged minority ("aristocracy") of protected and stable workers; b) 
a "non-class of non-workers" whose activities are precarious and increasingly focused on the provision of personal services (the reconfiguration of a "class of servants"); and c) a mass of unemployed people. The political consequence of this way of exposing the social process leads him to consider that the "stable and privileged" minority of workers will, consciously or otherwise, make alliances with employers and dissociate themselves from what would be their "contrary", i.e. precarious workers (1988, 66-68).

Claus Offe, in turn, faces the question of whether, given the totality of these transformations, the loss of objective importance of work was matched by the loss of subjective relevance in the sense of constructions of identities and expectations for the future. According to Offe, it would, therefore, be possible to speak of the loss of the centrality of work or "the crisis of the labor society to the extent that accumulating evidence that shows formal paid-work has lost its subjective quality as the organizing center of human activities, self-esteem and social references, as well as moral orientations" (1989, p.7).

Using, as Gorz did, the claim that the set of wage earners had been deeply fragmented by technical changes, Offe points out that one of these new segments would be found in the form of service work. This is the main point for our analysis because, according to Offe (1989, pp. 22-23), service work would have a "distinct rationality", qualitatively different from activities in industry. That is, and this is the most important characteristic, a "reflective work" in the sense that one elaborates and maintains his/her own work. Two differences in relation to the traditional model arise. First, due to the "heterogeneity, discontinuity and temporal uncertainty of the activities ... it would not be possible to standardize a technical work function to be adopted as a criterion for controlling the execution of work". Second, Offe draws attention to the inexistence of an unquestionable "criterion of economicity", that is, the impossibility of strategically planning "the type, volume, location and timing of its supply."

The repercussions of this debate in the academic field of labor studies relations were extensive $^{3}$. In the Brazilian debate, Antunes (1995) elab- orated a critique of the "farewell to work" which, among other arguments, highlighted two limits to this theoretical position. The first was the Eurocentric character of the diagnostics carried out by the authors, as the globalization of the capitalist productive circuit re-created millions of typically-industrial jobs in other regions of the world. Second, Antunes argued that the industrial and services sector have more similarities than differences, even in Europe. Indeed, the neoliberal offensive on the regulation of employment encourages forms of employment distinct from the Fordist pattern, but this did not imply a qualitative and quantitative reduction in the existence of wage-earning groups whose lives were subsumed by capitalist logic.

It is important to observe that our critical approach to the first farewell to work and the working class does not mean disregarding the magnitude of the phenomena that were the object of this discussion. There was a marked shift in the occupational structure in several central countries and a growing part of the workforce was embedded in flexible forms of hiring. The picture was even more potent in the case of countries with dependent capitalism that already had informality or precariousness as the main feature of their labor markets.

But the point that seems most decisive is that this farewell to work was informed by a diagnosis of the situation which gave technological change a prominent and unavoidable role. Thus, a causal relationship was established between what would be the loss of relevance of labor as a source of wealth - or even the supposed difficulty of measuring some economic activities - and the difficulty of reconstructing stable patterns of employment regulation. The determination was presented as more technical than political and social. It is precisely this point that constitutes the link between the first and what we describe here as the new farewell to work.

\section{The new farewell to the working class}

We call a new farewell to the working class a set of theoretical and analytical interventions that, despite their political heterogeneity, radicalized the premises formulated in the first theses of the 1980s. The distinctive feature of this argumentation is the 
emphasis given to what would be a structural decline in wage labor and the impossibility of rebuilding patterns of employment regulation by means of legal provisions. In other words, as if the so-called new forms of work organization were phenomena determined by technical imposition and not as a result of political disputes.

On the one hand, a noteworthy change in this new argument is that, unlike the first one, the notion of an end to work in general, as stated by Gorz, is less explicit. Furthermore, the current one stresses that not only industrial labor, but all wage labor would be in decline in the face of the rise of "new forms" of work organization. What is in question is the impossibility of recovering or constructing employment regulation patterns based on the notion of an employer and an employee. On the other hand, the basis for these assessments, as in the first farewell, is the prominence of the technical determination of social relations to the detriment of the political and economic strategies that affect the regulation of employment.

The new farewell to the working class comes from different perspectives but is based on similar assumptions and reaches similar conclusions: a) wage employment is declining and b) new features of labor markets prevent labor regulation via regular labor law.

There are at least three different approaches joining the new farewell to the working class. The more radical one assumes that self-employment is increasing and there is a trend to replace wage employment in labor markets. The second approach states that new forms of work are growing, which neither fit in with wage work nor with self-employment, constituting what is called a "grey area" or "third way of working". The third one is presented by Guy Standing $(2011,2014,2016)$, and is summarized by his concept of "precariat", a new social class that would be growing while the salaried and the proletariat would be shrinking worldwide.

The first two approaches are normally combined as an argument to emphasize the shift on labor markets. They appear, for example, in an International Labour Organization (ILO) publication from 2015, suggestively called "the changing nature of jobs":
In a number of advanced economies, the incidence of wage and salaried employment has been on a downward trend, thus departing from historical patterns. Conversely, own-account work and other forms of employment outside the scope of the traditional employeremployee arrangement are on the rise (ILO, 2015A, p.13).

These considerations are normally based on the following arguments:

New technology and changes in the way enterprises organize production are key factors behind the shift in employment relationships and the spread of new forms of work. Achieving the standard employment model for the majority of workers is becoming more difficult. (ILO, 2015A, p.14)

The assumption that "new forms of work" have been increasing is also very relevant in underdeveloped countries, such as Brazil, which can be theoretically based on the crisis of Fordism as a pattern of organizing labor:

The end of the Fordist pattern of labor - as a norm, which does not prevent the existence of work featured as Fordist - requires reflection on the various forms and differentiations that work and employment assume. These differences are in the origin of the "scrambling" of wage boundaries and the establishment of a "gray zone" for the new employment relations. This "gray zone" requires both the revision and the creation of new concepts within the sociology of work. (...) Among the emerging forms of insertion through work, self-entrepreneurship stands out as the emblematic object of a work relation in substitution of an employment relationship, since becoming own-account entrepreneur means a form of distension of wage employment (Rosinfield, 2015, p. 116).4

Beyond the academic field, business interests are keen to pressure public regulation using the new farewell hypothesis. For instance, according to 
the Financial Times: "As technology and globalization disrupt and fragment the world of work, some lawyers warn legal employment statuses are too oldfashioned to capture the complexity of many modern employment relationships" (O'connor, 2015)

The increase of "new forms of work" and the need to reduce labor regulation have been strongly claimed by private institutions, like the National Confederation of Brazilian Industrial Employers (CNI):

The spread of information technologies has created a new world for work. There are knowledge-intensive activities that can be developed by a group of people spread out around the country or around the world. Being specialized, this type of worker can match the attendance to demands from different companies. You can work at home, without wasting time in traffic, determining your schedules in the way that suits you best. However, the modern working relationships of the 21 st century are still regulated by obsolete norms of the first half of the 20th century (CNI, 2010, p.109).

This picture has predictably influenced public regulation. In 2015, the UK government published an Employment Status Report carried out by the Office of Tax Simplification. According to its Director John Whiting:

This system of two alternatives can be seen as a traditional view of the labor market. People either worked, normally full-time, for an employer; or they were clearly self-employed: the local plumber for example. But that traditional labor market has changed significantly in recent years:

(...). This made sense in the 1950s and 1960s but the huge growth in freelancing as a way of life (and work) doesn't fit readily into this traditional model. That growth stems from the IT industry, but has spread far beyond it, facilitated by the internet and (nowadays) 'apps'. Some people may be forced into this form of working but more choose it and value the flexibility it brings. All of this leads some to suggest that the tax system needs to recognize a 'third way' of working.(...) there has been a considerable growth in people working on their own but taking on roles in an organization for a period, sometimes on an exclusive basis but often whilst working elsewhere. These people may have no desire for traditional employment rights; they are often termed freelancers or contractors. (UK, 2015, P. 2)

This "new world of work" featured by the spread of new forms of work is also assumed by Guy Standing $(2014,2016)$. According to him, the world is experiencing a "Global Transformation" analogous to the "Great Transformation" identified by Karl Polanyi (1944). Today, however, a global market system has been built, whilst Polanyi analyzed the creation of national market economies. The precariat emerged from this new framework, a new class characterized by chronic uncertainty and insecurity. Standing asserts that the precariat has different relations of production, distribution and citizenship compared to the salaried and the proletariat. The precariat is inherently unstable, its members are always ready for an uncertain job and have no control over their time and depend exclusively on salary to survive (they have no labor rights). In short, Standing affirms that while during the Great Transformation national capital admitted a stable work for the core of the proletariat, today global capital imposes complete instability on the precariat. The author sees this difference as fundamental to discriminate the precariat from other classes.

For Standing, we are experiencing a revolution in forms of work that makes previous regulation unfeasible to protect workers and reduce inequalities. The type of work that grows faster is what he calls "crowd work", carried out by the taskers, who are part of the precariat and perform activities with no labor rights, stability or income guarantee. The taskers work via labor brokers, new corporations such as Uber. Standing considers these corporations to be rentiers, since they do not own the means of production. According to the author, the taskers:

(...) are not employees, since they are not directly supervised, own the main means of production and, in principle, have control over their working time. (...) They are not self-em- 
ployed either in that they depend on the labor broker for access to the apps. But they have to bear most of the risks, of accidents, ill-health, repairs and maintenance. They are well within the precariat. (Standing, 2016)

Standing states that the old system characteristic of labor regulations is inadequate for current realities, defending that a universal basic income must be the public policy to address the precariat.

Therefore, what we are calling the new farewell to work, the idea that wage employment is declining and labor law is not a solution for the current context, seems to bring together many different ideological perspectives.

Our main question is: Does the new farewell to the working class show empirical consistency?

\section{Empirical evidence of the new farewell to the working class}

In this section, we are going to test the empirical consistency of the new farewell to the working class.
First, we will show some available data concerning wage employment around the world in the last decades. Then, we will briefly present some case studies that we have carried out in Brazil and the United Kingdom, inquiring about the effective content of these employment relations beyond what companies declare about them. Our main goal is to detect if the "new forms of work" are truly different in their nature from traditional employment.

\section{Is explicit wage employment declining?}

The first main indicator that seems to be forgotten in the debate about the recent shift in work relations is the proportion of wage employment in total employment. Despite all the claims of the growth of new forms of work, explicit wage and salaried employment has been growing around the world in the last decades. From 1991 to 2014, wage and salaried labor has increased in all continents, including developed economies, as the following figures taken from ILO (2015A) show.

Even in central and south-eastern Europe, where wage employment fell between 1991 and

Graphic 1

Wage and Salaried Employment (\% of total employment), World and Regions

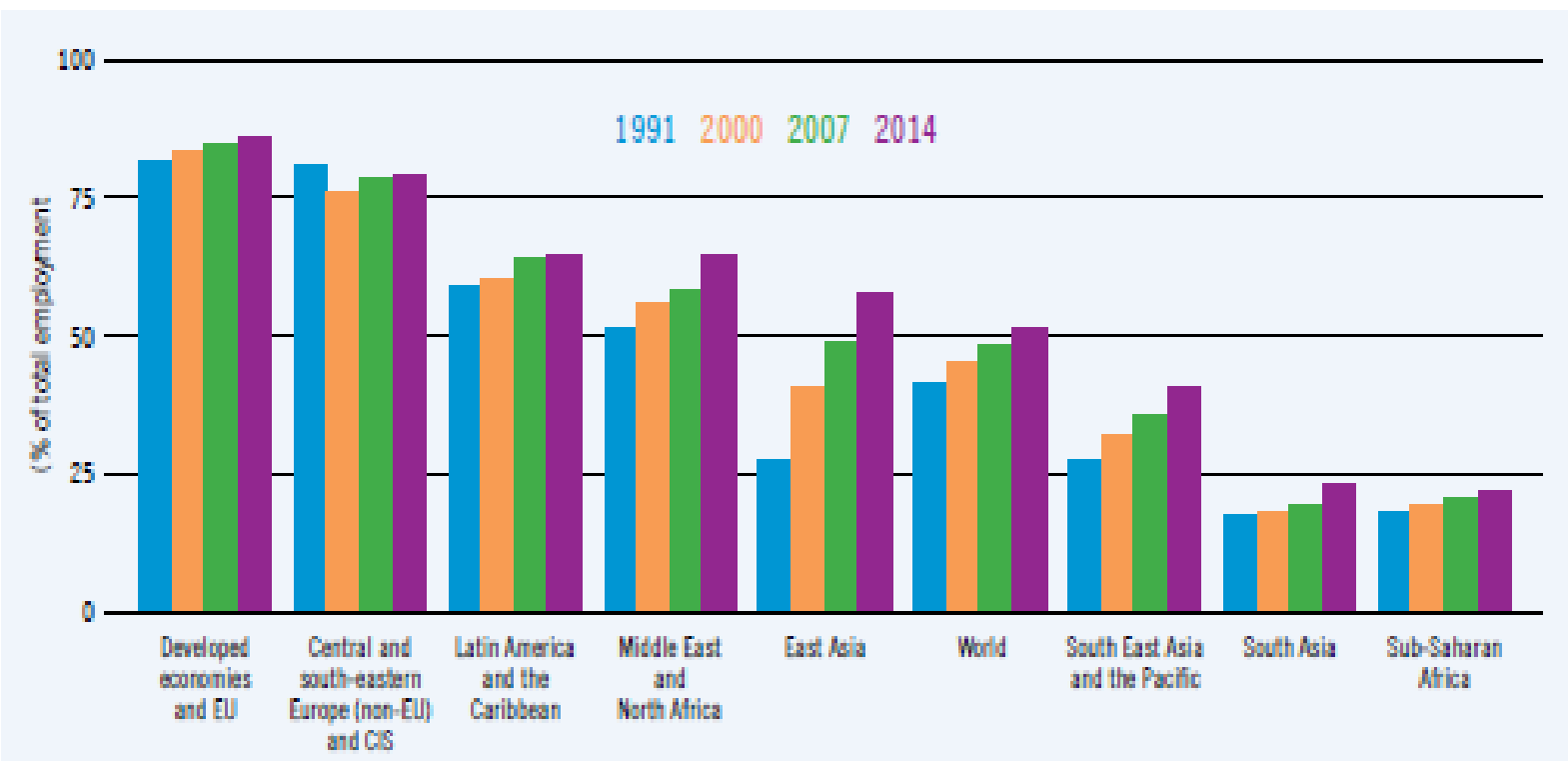

Source: ILO, Trends Econometric Models, October 2014 (ILO, 2015, p. 28). 
2000, the trend after this period shows the recovery of wage labor as a proportion of total employment. By 2014, wage work had surpassed half of total employment in the world.

So, the so-called new forms of work, which are likely to be classed as self-employment, do not represent an important percentage in the most developed economies and even in Asia and Africa there seems to be a trend of growth of wage employment.

In Latin America, among 18 countries between 2005 and 2014 the proportion of wage employment raised from $61,1 \%$ to $65,1 \%$ of total employment, while self-employed oscillated from 22,9\% to $21,9 \%$ during the same period (ILO, 2015B, p. 42). Overall, there is no tendency of wage work declining in any part of the world.
More recent available data from ILO data base (ILOSTAT) corroborate this growing trend of wage labor in total world employment, as presented below:

While employers and own-account workers keep stagnated on their participation rate from 2000 to 2018 , the number of employees in the world's labor market increases gradually and systematically during the same period. It's worth mentioning that this trend is also seen when considering only highincome countries, as presented in Table 2 .

In this sample of countries, probably the most affected by the alleged shift in work relations, selfemployment is still far from representing a threat to the pattern of contracts. Indeed, this type of employment faces a small reduction between 2000 and 2018. Meanwhile, employees constitute the vast

Table 1

WORLD: Types of Employment, Participation Rate (\%) In Total Employment

\begin{tabular}{lllll}
\hline Year & Employees & Employers & $\begin{array}{l}\text { Own-account } \\
\text { workers }\end{array}$ & $\begin{array}{l}\text { Contributing family } \\
\text { workers }\end{array}$ \\
\hline 2000 & 45,7 & 2,7 & 35,1 & 16,4 \\
\hline 2001 & 46,0 & 2,8 & 35,0 & 16,2 \\
\hline 2002 & 46,3 & 2,8 & 34,9 & 16,0 \\
\hline 2003 & 46,4 & 2,8 & 34,9 & 15,9 \\
\hline 2004 & 46,8 & 2,9 & 34,7 & 15,6 \\
\hline 2005 & 47,3 & 2,9 & 34,5 & 15,3 \\
\hline 2007 & 47,9 & 2,9 & 34,4 & 14,8 \\
\hline 2008 & 48,4 & 2,9 & 34,4 & 14,4 \\
\hline 2009 & 48,9 & 2,9 & 34,3 & 14,0 \\
\hline 2010 & 48,9 & 2,9 & 34,5 & 13,7 \\
\hline 2011 & 49,3 & 34,5 & 13,0 \\
\hline 2012 & 49,9 & 34,2 & 12,7 \\
\hline 2013 & 50,6 & 2,9 & 33,9 & 12,3 \\
\hline 2014 & 50,9 & 34,0 & 12,0 \\
\hline 2016 & 51,2 & 33,9 & 11,6 \\
\hline 2017 & 51,5 & 34,0 & 11,4 \\
\hline 2018 & 51,7 & 34,9 & 11,1 \\
\hline & 51,9 & 34,1 & 34,9 \\
\hline
\end{tabular}

Source: elaborated from the ILOSTAT database. 
majority of total employment, experiencing a small increase in their participation in total employment.

Some countries, such as Brazil and the UK, have been experiencing periods of growth of selfemployment, but as we will see, the process is neither permanent nor inexorable and depends on political options of labor regulation combined with labor market performance. In the UK, after considerable increase in self-employment post the 2008 crisis, wage employment corresponds to $85 \%$ of total employment in the country.

Therefore, the debate over new changes in work relations must consider that, at least up to the present moment, there is no sign that new forms of work are replacing wage employment.

It is worth emphasizing that the statistics pre- sented so far come from types of contract declared in surveys, which means that disguised relations are not being taken into account. Our next step is to show some findings of the so-called new forms of work in the UK and Brazil, with the aim to point out the actual nature of these arrangements.

The nature of the new forms of work

This section addresses the following questions: are the new forms of work truly new in terms of content? Or are they in fact wage employment intentionally presented and claimed by companies as different forms of work?

Initially it is important to stress that part of the statistics for self-employment exhibited in na-

Table 2

HIGH INCOME COUNTRIES: Types of Employment, Participation Rate (\%) In Total Employment

\begin{tabular}{lllll}
\hline Year & Employees & Employers & Own-account workers & $\begin{array}{l}\text { Contributing family } \\
\text { workers }\end{array}$ \\
\hline 2000 & 84,4 & 4,0 & 9,6 & 2,1 \\
\hline 2001 & 84,5 & 3,9 & 9,6 & 2,0 \\
\hline 2002 & 84,7 & 3,8 & 9,6 & 1,9 \\
\hline 2003 & 84,7 & 3,9 & 9,6 & 1,9 \\
\hline 2005 & 84,8 & 3,9 & 9,6 & 1,8 \\
\hline 2006 & 85,0 & 3,8 & 9,5 & 1,7 \\
\hline 2007 & 85,3 & 3,8 & 9,3 & 1,5 \\
\hline 2008 & 85,6 & 3,8 & 9,2 & 1,5 \\
\hline 2009 & 85,9 & 3,8 & 9,0 & 1,4 \\
\hline 2010 & 85,9 & 3,8 & 9,1 & 1,3 \\
\hline 2011 & 86,0 & 3,7 & 9,0 & 1,3 \\
\hline 2012 & 86,2 & 3,6 & 9,0 & 1,2 \\
\hline 2013 & 86,4 & 8,9 & 1,2 \\
\hline 2014 & 86,6 & 8,8 & 1,1 \\
\hline 2015 & 86,7 & 8,8 & 1,1 \\
\hline 2016 & 86,9 & 8,6 & 1,0 \\
\hline 2017 & 87,0 & 3,4 & 8,7 & 1,0 \\
\hline 2018 & 87,1 & 3,4 & 8,6 & 0,9 \\
\hline
\end{tabular}

Source: elaborated from the ILOSTAT database. 
tional surveys worldwide, especially in underdeveloped countries, are actually independent workers that engage themselves in activities (normally precariously) on their own accord. Owners of small businesses such as barber shops, market and street workers, domestic maintenance (plumbers, electricians, etc.), small farmers, etc., have always existed and will probably always exist in any capitalist society. Thus, there is no news in these situations.

The subject approached here is the "new forms of work" that allegedly emerged in recent transformations of capitalist societies. We chose some cases which we considered representative due to their incidence or recent increase. It is important to highlight that our main intention here is to now identify different forms of contracts by focusing on concrete examples.

\section{Construction sector in the UK}

The construction sector is a good example for analysis. It is one of the main sectors in regards to employing people in the UK (about 2 million workers) $)^{5}$. In the UK, the sector has one of the highest numbers of workers contracted by companies as self-employed. Official data indicates that $39 \%$ of total employment in this industry is classed as "self-employed". The construction sector represents about $20 \%$ of all self-employment in the UK (ONS, 2014). The demand for increased flexibility in the new capitalist context is one of the explanations given to this situation.

Companies commonly hire workers classed as self-employed through employment agencies or using "umbrella companies". Despite different formal appearances, the cases we investigated all share a common factor in that the workforce continues to be managed by the main company. The main difference between workers (employees or self-employed) on the building sites is simply how they are hired.

For instance, at a building site in London that we visited in July 2015, similar to most sites in the UK according to other sources, there were 90 workers. However, the main company contracted directly only 5 of them: a subcontractor hired 10 electricians, 15 were agency employees, and 60 were hired through agencies as self-employed. Some of these "self-employed" workers hired through agencies had worked for years for the same company. The formal employees were engineers, supervisors and those at the top of the site hierarchy, which means, the ones that determine what, where, when, and how work should be done. To exemplify how the activities were organized, the crane operators, hired as self-employed, were forced by the company to work ten hours a day, instead of four, which is the legal working day.

In 2016, the House of Commons published a Briefing Paper over this issue. It brought some information related to the use of self-employment by companies as a strategy to undermine labor law:

In May 2008 the Union of Construction, Allied Trades \& Technicians (UCATT) published a report it had commissioned from Professor Mark Harvey, at the University of Essex. The author suggested that around $30 \%$ of the workforce - 375,000 to 425,000 - were inaccurately engaged as self-employed.

\section{(...)}

In 2007/08, the Government estimates that there were 300,000 subcontractors operating within [CIS] who did not claim any deduction for the costs of materials, nor for plant and equipment. These subcontractors provided none of the materials or plant and equipment which would form a substantial element of any contract and provided only their labor (Seely, 2016, p. 13-14).

According to research carried out by FLEX (Focus on Labor Exploitation):

In the construction sector there is widespread use of self-employment as the preferred contracting arrangement. Self-employed workers have significantly fewer rights than those employed directly by a company. The former union for workers in the construction sector, UCATT - now merged with Unite - asserts that there is a direct link between these types of employment arrangements and exploitation, 
and in many instances employees are not really working for themselves (FLEX, 2017, p. 8)

There are strong indications that the spread of self-employment in the British construction sector is strictly related to strategies to manage the workforce, instead of some modification in the nature of work relations on the building sites.

Logistics: the couriers in the UK

Another good example of the supposed new forms of work in the UK is the logistics workers. Big companies (such as large banks) use intermediaries to hire workers at the lowest cost and highest flexibility. We interviewed workers linked to six different intermediaries, and we also analyzed documents (payroll) and equipment (radios and control equipment) ${ }^{6}$. In this sector, practically all workers are formally hired as self-employed, with no labor rights. They are also obligated to pay fees to the intermediaries and have no minimum payment guarantee. Instead of having more flexibility, the couriers tend to work harder and rest less than the average worker because they have no job security and need to make an effort to compensate the low rate they get for each delivery. They get no paid holiday and no income when they are sick or if they suffer any work-related accident.

The situation of these couriers has even caught media attention. There have been reports from The Guardian and the BBC regarding the issue ${ }^{7}$. Some of the workers that we had personally interviewed in London were approached for these reports. For instance, Mario Gbobo, who fell off his bike and suffered a bad injury to his arm, talked to the BBC about the accident:

The parcel I was carrying was insured, but I wasn't," he said. "Someone came and collected the parcel. I had to fend for myself and ended up returning to work before the injury healed because I needed the money.

Another courier interviewed by the BBC, Andrew Boxer, stated that:
"I am typical," he said. "I work for one company for around 50 hours a week. They tell me what to do, when to do it and how to do it. I am monitored, have to have company ID with me at all times, and can't take work from other companies. I get paid per delivery, not per hour. I am required to sign a contract which says that I am self-employed, which means I don't get any employment rights."

The management of the workforce by the main companies that employ couriers is carried out by a kind of Dutch auction, in which the intermediary that offers workers for the lowest bid wins the contract to provide the workforce. Although it might seem tricky, the so-called sharing economy, including internet arrangements and services controlled by apps, has submitted workers to even more challenging conditions than traditional employment.

Sharing economy: the case of the translators

Around the globe, there has been a massive increase in services offered via internet, like law advisement, engineering and many others. This way of organizing production is known as sharing economy, platform economy, or crowd labor. Companies that own the webpage make the link between customers and service providers. The claim is that this kind of company would have customers but none employees. These providers would be selfemployed who allegedly command their own business, using the webpage only as a platform to reach clients. However, the real picture is far from this superficial description.

We interviewed a translator based in London that works with this type of arrangement. He also gave us access to his emails and documents to demonstrate how the labor process is organized, providing us with enough research material to draw statements regarding the dynamics of this sector. To summarize, the company hires a pool of formally self-employed translators (who, in principle, may work for other firms). To join this pool, the translator must complete a test, submit his credentials, sign a contract and other documents. Once this is complete, every time there is a translation available, 
the workers receive an email with a price to be negotiated. Whoever first offers a price considered satisfactory by the company, wins the job. The translator explained that "it is like a speeded-up, globalized 'just in time' version of what existed previously. A job may be worth just $\$ 10$ !” He goes on to specify how the production and labor process is carried out.

(...) the process has become much more automated. It means that the more market share an agency has, the more its workers have to be on 24/7 alert to answer any job offer. So you can spend a lot of time bidding for jobs but not getting them (unless you cut your rates). Financially it is a race to the bottom.

The company selects who can be hired to form the pool, and then organizes the labor process via an auction among the workers to choose who will receive each job. Finally, it imposes when and how the translation must be done, as we can see in the following email:

How are you today? Hope all is well. We have a rush Spanish > English (US) translation around 1200 words we need your help with!

BACKGROUND: Clinical; INSTRUCTIONS: Please follow source format as closely as possible! Please match date format. Please denote any text that is illegible in brackets (i.e. [illegible]); Please copy/paste logos. Please copy/paste numbers and any English text; Please redact all patient information. Please indicate handwriting in italics as well as a note in brackets i.e. [hw].

DELIVERABLE: One Translated Word Document

TRANSLATION DEADLINE: 11AM EST, Wednesday, 7/22. Please let us know if you are available for this job.

The job mentioned in this email was offered 10:23am and had to be done by 4:00pm. As stated by the translator, this is a typical email sent by the company. For him, the meaning of the process is: "you must drop everything and do it now! This is aimed to get a maximum response (i.e. fiercest competition) from us, the global pool of translators".

This Dutch auction carried out in the sharing economy is even worse than those arranged in other sectors because it directly involves workers themselves in price negotiations. Standing (2016) has also described this management strategy, which he calls a crowd labor pool:

What happens is that platform companies contract to have certain jobs done for corporations, and in turn designate labor requesters to contract out jobs to people invited to compete in a Dutch auction. Requesters announce that so many tasks are up for bid, with a stipulated deadline, and that bidding will close within, say, five days. Often, the requester announces at the outset a maximum piece rate. Then taskers can bid to undertake as many tasks as they think feasible at a price they think is right. At the end, requesters select from the lowest bids. So, somebody in Boston can be competing with someone from Bangalore or Accra. This is invidious, since the most insecure will tend to bid the lowest. As they do not know how many are bidding or where they are, they may believe competition is more intense than it is. For the broker, that is ideal. And the tasker has no assurance he will be paid. If a broker, based in New York, decides that a tasker in Dakar did not do something well enough and refuses to pay, in practice the tasker has no means of redress.

Standing's description shows how this mechanism of hiring workers, which has become increasingly common in various types of activities, operates. The profits of these companies are directly linked to the insecurity and precariousness of those who need to accept the tasks to ensure their survival. Our divergence from Standing's argument is that the solution proposed by him - the introduction of a universal basic income as a way of eliminating the economic coercion imposed on those who must accept the tasks - considers it impossible to regulate these jobs through labor law. It is precisely this point 
- the need for legal recognition of the employment status - at the core of the political struggle, not the current technical/economic picture.

Some examples from Brazil

In Brazil, many different arrangements claim to be new forms of work. Although many of them have been used for decades, they are joining the recent wave of organizing labor and production process avoiding employment status.

For instance, there are over a million so-called consultants from cosmetic companies that sell cosmetics classed as self-employed (Abilio, 2014). Beauty shops allege to "rent" seats for hairdressers to work for them. It is common in the health sector to see employers hiring workers through labor cooperatives. Companies from all sectors hire workers via commercial contracts as if those people were an enterprise of just one person. It has happened from the construction sector to chemical factories. In all these cases, despite being labelled and hired as selfemployed or even as firms, workers are submitted systematically, controlled by the contractor and are subject to the companies' will more so than formal employees (Filgueiras, 2012, 2016).

One of the most common new forms of work, particularly in rural business, is called "integrated production". In sum, the "integrated worker" is a small farmer that signs a contract of exclusivity to perform some activity that is part of a company's business, for instance, planting tobacco for a cigarette company.

This "integration production" is not merely a monopsony since the process of work and production performed by the integrated workers is controlled by the so-called single buyer. Activities carried out by integrated workers constitute part of the main company's business. The latter owns the products themselves (tobacco, eggs, birds, pigs, etc.), supplies the raw material and the inputs, imposes the technical standards of the activity, commonly finances facilities, among other things, while the integrated worker must attend exclusively to the company's demands. The integrated worker delivers the production at the time and in the conditions desired by the company (Filgueiras, 2013).
The integrated worker has an entirely flexible income (depending exclusively on production results) that is divided with their families, without a guaranteed minimum wage, paid holiday or payment for overtime, even while working every day of the week. In a study carried out by Filgueiras (2013) in the poultry sector of Bahia, child labor was widespread, a mechanism adopted by the integrated worker to avoid corrosion of the already scarce family income, which also seems to be common in the production of tobacco in the southern region of Brazil (Brasil, 2007). Blatant disrespect to the minimum parameters of labor standards was detected in egg production and broiler sheds, a reality that also seems to be frequent in the rest of the country, including cases of slave-like conditions $^{8}$. The "integration" arrangement is an essential instrument for the exercise of control and exploitation of labor in these businesses. When labor law is completely disrespected, workers are obliged to work for longer hours and more intensively, rarely resting, working every day uninterruptedly to ensure a minimum income necessary for survival (Filgueiras, 2013).

\section{UBER}

UBER is a worldwide known company that presents itself as an app that provides services to drivers. In one instance, in a lawsuit in the UK: "Uber's argument was that it was a technology company and that it did not provide a transport service to customers - it merely put them in touch with drivers"'.

In Brazil, UBER drivers do not have any formal contract with the company, but they must follow a series of requirements to be admitted. Despite the rhetoric of working time flexibility, when UBER is starting its operation in a city, they attract drivers by making fixed payments for performing working day journeys. The rates paid to drivers vary by the time of day and the region of the city, inducing drivers to work according to the company's demand. UBER unilaterally imposes the rates it gets from each ride, which also oscillate by city, season, etc. The drivers' behavior must follow company guidelines, whether related to the customer or regarding the conditions of the car. All payments are made directly to UBER (there are exceptions, but the amount is then deducted from the next rides). Drivers can not directly 
arrange rides with customers, refuse animals, take another person in the vehicle, perform other services while they are with passengers, share the car to use their UBER registration, request private information from passengers, among several other requirements that must be fulfilled in the labor process. UBER permanently evaluates drivers through the customers, who evaluate the driver by the application at the end of the ride. The company makes clear that "attitudes that harm the platform, users or other partners can also lead to deactivation" even if they are not pre-listed ${ }^{10}$, in other words, the worker can be dismissed for any reason UBER considers applicable.

In such new forms of works, such as UBER, self-employed couriers, crowd labor pool and "integrated production", companies turn the means of productions (vehicles, facilities, computer, land, etc.) into their capital without needing formal ownership over them, reducing investment and fixed capital, while at the same time pulverizing and transferring the risk of business to each worker, intensifying the spiral of pressure on the individual. Besides, it facilitates the legitimacy of the discourse of "autonomy", "flexibility" and "entrepreneurship" among workers, reducing their propensity for contestation and collective action.

Furthermore, exclusive labor markets emerge from these arrangements, weakening the bargaining power of workers that have to compete inside the company for jobs by lowering wages and working conditions. In the case of UBER and platform companies, they intentionally seek to form a stock of workers available to compete with each other, allowing these firms to pay meager salary. The rates are always varying, set per piece (ride, translation etc.), forging a system in which tasks available are driven by the logic: "who accepts the price first, takes the job".

So, despite not being the formal owner of the means of production, companies can control the process of work and production through other means (e.g., monopolizing the interface with customers). Not owning cars, bicycles, computers and small lands is a great advantage for companies, since they do not need to immobilize capital and transfer the business risks to workers, making them more insecure and less likely to confront orders.
A point of view, such as that of Standing, which emphasize that the worker owns the means of production, highlights formality rather than the actual content of relations. It is worth remembering the distinction between the legal notion of ownership and effective power of the means of production made by authors such as Poulantzas (1977) and Betellheim (1976). In the cases discussed here, companies do not have formal rights to manage cars, bicycles, computers, etc. However, they have the effective possession of the means of production through two dimensions. Firstly, as we have indicated for UBER, the driver, the formal owner of the automobile, loses the ability to define the terms of the contract with users. He is the "UBER" to the person who calls him, having to respect a code established by the company, not a contractual relationship between him and the user. Secondly, UBER is able to control the crew of drivers via increasing or decreasing rates and imposing conditions to guarantee the demand and supply of cars, and workers to perform the rides. In short, the company does not need legal ownership of automobiles because it already has its effective possession.

Besides making it harder for individual resistance and collective action, these arrangements have undermined protective regulation of labor by states. The narrative that publicizes these arrangements as new forms of work implies a new farewell to the working class, more radicalized than the first farewell, but based on the same core: wage employment would lose its relevance in society. Previously, the predictions focused on industrial labor, however, now they address wage employment as a whole. The world of work would be experiencing new ways of organizing work and production beyond wage work, the growth of self-employment, "grey areas", undetermined relations, in any case, relations that are not suitable to labor law regulation.

It is worth emphasizing that companies have deliberately denied the status of wage employment for their workers as a critical tool to manage their labor and production process. By claiming their workers are self-employed or that these individuals are companies themselves, employers undermine workers' conditions to impose limits to exploitation, preventing them from having access to labor rights, dismissing them more easily, and inhibiting 
individual or collective mobilization. Therefore, these workers are more precarious and even more submitted to companies' orders.

Even official documents from the UK's Government stress that the use of self-employment status is intentionally used to undermine workers' rights and conditions, which is related to labor exploitation across many sectors in the country. A report from the Gangmasters And Labor Abuse Authority (GLAA, 2018), released in May 2018, scrutinizes this strategy in the cleaning, flower picking, car washing, food processing and construction sectors. In Brazil, this picture is widely acknowledged by institutions that regulate labor law, although they have not been efficiently tackled (Filgueiras, 2012).

\section{Participation of self-employment in total employment}

To evaluate possibilities of labor regulation in the current context, it is essential to analyze the dynamics of types of contracts in total employment in two countries that have or are still experiencing the increase in new forms of work, most likely to be represented in official data as self-employed status.

In the UK, throughout the 1980s and until the mid-1990s, there was a trend of growth of selfemployment (considering the sum of employers and own-account workers) in total employment. In 1995 , self-employment reached $13,8 \%$ of total employment. However, during the subsequent period the proportion of self-employment declined to $11,8 \%$ in 2000 :

Table 3

UK: Types of Employment, Participation Rate (\%) In Total Employment

\begin{tabular}{lllll}
\hline Year & Employees & Employers & $\begin{array}{l}\text { Own-account } \\
\text { workers }\end{array}$ & $\begin{array}{l}\text { Contributing family } \\
\text { workers }\end{array}$ \\
\hline 2000 & 87,73 & 3,2 & 8,68 & 0,4 \\
\hline 2001 & 87,8 & 3,16 & 8,69 & 0,35 \\
\hline 2002 & 87,69 & 3,05 & 8,93 & 0,34 \\
\hline 2004 & 87,18 & 3,01 & 9,51 & 0,3 \\
\hline 2005 & 86,91 & 3,05 & 9,7 & 0,35 \\
\hline 2006 & 87,01 & 2,94 & 9,72 & 0,34 \\
\hline 2007 & 86,77 & 2,93 & 9,97 & 0,33 \\
\hline 2008 & 2,88 & 10,16 & 0,34 \\
\hline 2009 & 86,61 & 2,81 & 10,19 & 0,34 \\
\hline 2011 & 86,66 & 10,52 & 0,3 \\
\hline 2012 & 86,4 & 2,78 & 11,02 & 0,32 \\
\hline 2013 & 86,01 & 2,65 & 11,31 & 0,35 \\
\hline 2014 & 85,82 & 2,52 & 11,74 & 0,36 \\
\hline 2015 & 85,38 & 2,52 & 11,76 & 0,37 \\
\hline 2016 & 85,41 & 2,47 & 12,32 & 0,38 \\
\hline 2017 & 84,77 & 12,22 & 0,33 \\
\hline
\end{tabular}

Source: elaborated from the ILOSTAT database. 
Even though it re-established a trend of growth, it took until 2012 for the proportion to surpass that of 1995 .

The debate over the increase of self-employment has been intense. However, it is also important to stress that between 1991 and 2014 self-employment growth represented only an extra 1,9\% in total employment, while wage employment remained a massive majority of total employment $(85 \%)$, above average in comparison to all other regions of the world.

For more than two decades, the changes have not been substantial. Wage employment remains representing the vast majority of total employment, and oscillations in forms of engagement in the UK labor market indicates that there is no inexorable trend in any direction.

The Brazilian labor market has experienced a similar path. During the 1990s, the deterioration of the labor market was concomitant to the rise of self-employment. However, from the 2000s, economic expansion was accompanied by an increase in wage employment for more than 10 years.

The proportion of employees in total employment raised from $54,2 \%$, in 2002 , to $61,8 \%$, in 2012, while self-employment fell from $22,3 \%$ to $20,7 \%$ in the same period. Since 2012, simultaneously with the current economic crisis in Brazil, self-employment started to increase once again while formal wage employment has fallen.

Table 4

BRAZIL: Types of Employment, Participation Rate (\%) In Total Employment

\begin{tabular}{lllll}
\hline Year & Employees & Employers & $\begin{array}{l}\text { Own-account } \\
\text { workers }\end{array}$ & $\begin{array}{l}\text { Contributing family } \\
\text { workers }\end{array}$ \\
\hline 2000 & 62,99 & 4,42 & 26,1 & 6,49 \\
\hline 2001 & 63,2 & 4,38 & 26,56 & 5,86 \\
\hline 2002 & 63,06 & 4,41 & 26,7 & 5,83 \\
\hline 2003 & 63,00 & 4,34 & 26,92 & 5,74 \\
\hline 2004 & 63,56 & 4,24 & 26,45 & 5,74 \\
\hline 2006 & 63,47 & 4,39 & 26,58 & 5,56 \\
\hline 2007 & 64,26 & 4,61 & 26,19 & 4,94 \\
\hline 2008 & 65,42 & 3,87 & 25,95 & 4,76 \\
\hline 2009 & 66,45 & 4,62 & 24,97 & 3,96 \\
\hline 2010 & 66,95 & 4,42 & 24,87 & 3,76 \\
\hline 2011 & 67,84 & 3,95 & 25,03 & 3,19 \\
\hline 2012 & 68,51 & 3,47 & 25,32 & 2,7 \\
\hline 2013 & 70,11 & 3,99 & 22,89 & 3,01 \\
\hline 2014 & 69,85 & 23,05 & 2,98 \\
\hline 2015 & 69,97 & 4,12 & 23,16 & 2,75 \\
\hline 2016 & 68,67 & 4,12 & 24,21 & 2,39 \\
\hline 2017 & 68,22 & 4,38 & 25,11 & \\
\hline 2018 & 67,68 & 4,37 & 25,21 & 2,37 \\
\hline & 67,75 & 4,72 & & \\
\hline & 6,73 & & & \\
\hline
\end{tabular}

Source: elaborated from the ILOSTAT database. 
Between 2014 and the beginning of 2016, self-employment has increased repeatedly. In the middle of 2016 it fell sharply, but from the following quarter re-established a growth trend, reaching a peak of $25 \%$ in participation in the total employment in the country. The annual average of selfemployed workers increased from 20,5 million, in 2012, to 22,7 million in 2017.

When individuals are effectively self-employed, they can engage either in traditional and established forms of occupation (such as liberal professionals) or immediate survival strategies (such as street retailing). Besides, workers are classified as self-employed (the PNAD is based on the interviewee's declaration) even though they are salaried individuals from the most diverse activities (from rural work to so-called "digital platforms") who work in a subordinate way in relation to the taker of their services, as they refuse to admit that condition. An excellent example of this expansion of disguised self-employment is UBER. In Brazil, the number of drivers working for UBER multiplied by ten between October 2016 and October 2017, shifting from 50,000 to 500,000 drivers, considering only those who completed trips in the month of the survey (LOBEL, 2017).

These statistics help indicate that there is not an irresistible track to the way labor market is forged. Self-employment oscillates between growth and decline in the UK and Brazil depending on the economic performance and the choices made by private and public labor regulations. It means that we are dealing with a political phenomenon, associated with two questions: how capital has chosen to manage labor power during the neoliberal period, and how other forces in society have confronted or consented to the strategies of companies.

In Brazil, the average income of formal employees is substantially larger than informal employees (77\%) and self-employed workers (33.4\%). Comparing the first quarter of 2014 and the last quarter of 2017, only the average income of self-employed workers suffered a significant variation (a reduction of 9.2\%, or $\mathrm{R} \$ 159$ ). Thus, while the informal employees kept their historical precariousness, the supposedly autonomous workers saw their income getting further from those with a formal contract and approaching those without a formal contract.

Another indicator of the link between the expansion of self-employment and informal wage work and the precariousness of the Brazilian labor market in recent years appears in the number of contributors to Social Security. The average number of contributors in 2017 is the lowest since 2014 (59.4 million), as well as the percentage of contributors among the employed (64.6\% in 2014, against $64.1 \%$ in 2017), even with the growth of the occupation compared to 2016.

The fact that self-employed earnings are both lower and more unequally distributed than employee earnings in the UK (Office of tax simplification, 2015) does not seem to be a coincidence. All indicators suggest that self-employed income has fallen since the beginning of the 2000s. The median income per week of the self-employed adjusted for inflation in 2002/03 was $£ 290$, decreasing to $£ 207$ in 2012/2013 (ONS, 2014). There are signs that this is a global trend. As stated by ILO

In the majority of the countries self-employed incomes declined over the past decade, which could be due to the global recession and it is also probable that those who are laid off from paid employment enter self-employment depressing the incomes of the self-employed and leading to widening of the income gap (2015B, p. 42).

We should add that self-employment engaged in new forms of work probably plays an important role in this process.

Data from the UK also show that the selfemployed work more hours per week compared to employees (ONS, Labor Force Survey, 2014). Also, in 2013, the self-employed lost fewer hours to sickness than employees, respectively $1.2 \%$ of working hours and 2.1\% (LFS - ONS), corroborating our perception on the case studies. On average, the selfemployed have a lower income, work more hours per week and take less time off work. The supposed flexibility of the "new forms of work" seems to be more rigid than for wage employment. 


\section{The political implication of the new farewell: making it seem inexorable}

Despite being forged by evident wage work characteristics, the legal definition of the new forms of work is a political matter. The way it is defined imposes how it will be regulated and how people submitted to these arrangements will work and live. That is why we are facing essential issues that have already undermined people's quality of life during the last decades.

This political struggle regarding the framing of wage labor is as old as capitalism itself. Agreements and compromises that allowed limits to commodification of labor power are unstable and exposed to constant changes. Since the last decades of the twentieth century, there has been an international strengthening of what Dardot and Laval (2016) called "the new reason of the world". The power of neoliberalism is not restricted to its capacity to carry out legal changes or privatize public services. Since the beginning, it intends to design a new mentality aiming to make all individuals think and act as if they were companies. In this sense, it is crucial to deny any technical neutrality on the statement that "new" forms of work are not suitable to labor law, moreover as they are, indeed, wage labor.

It is important to emphasize that there is a fundamental difference between wage work and the concept of employee. The concept of employee is built to regulate a relation that is politically defined. It may embrace broader or narrower situations. For instance, the law may state that an employee is only applied to an individual who works for the same company over 10 hours each day, defining those not in this category as "freelancers". The law is a social relation and can be defined in any way as long as there is political power to impose it, regardless of the content of regulated empirical relations. Furthermore, it can define something in one direction today and switch to another direction tomorrow, depending on the political struggle related to the subject in dispute.

That is precisely the case of the new forms of work. The companies present their labor and process as "new" intentionally, among other reasons, in order to avoid labor law. They have created and helped to spread the "new ways of work" speech, as part of a new offensive regarding flexible ways of hiring workers. It is a strategy: avoiding to be seen as an employer is one of the main strategies of capital to manage labor in contemporary capitalism.

For the workers, it is harder to build identities and engage in collective actions. For the companies it helps to cut costs (avoiding labor rights, using flexible management etc.), to increase productivity (workers tend to be more dedicated, strikes are less likely to occur etc.) and even to increase subsumption of labor, since often the workers do not even recognize themselves as part of the production.

However, the new farewell to work has also influenced the role of state regulation, removing wage workers from the protection of labor law once they are not classed as employees. As scholars and institutions reproduce this idea of wage employment decline, they help to legitimize and make the deficit of regulation seem inevitable.

Wage employment does not seem to be declining, but its regulation depends entirely on the political struggle to regulate it. A fair discussion over the so-called new forms of work needs to rely on two main premises:

1. We must not take for granted the names companies state in contracts, or assume they define the actual relationship. Depending on the context, companies can attribute any terminology, and impose any condition to the contract, including the way activities must be performed, to favor their interests.

2. We must not confound the way in which the state regulates labor (which has been strongly influenced by the interests of companies) with the content of the phenomenon.

To summarize, we do not entirely refuse the content of the literature debated here. A portion of workers may deny their identity as wage workers and incorporate a business mentality, as if they were "capitalists of themselves". Due to the new strategies of companies, which have the denial of wage employment as a central aspect of management, the building of collective identity by work- 
ers becomes more difficult. It is not an incorrect perception of the literature, but an output of a long struggle over values and ideologies. Nevertheless, this picture is not enough to invalidate the possibilities of reinforcing protective regulation of labor.

\section{Final notes}

During the last decades, while the working class has weakened, capital has organized a framework of management that tends to reproduce and reinforce this weakness. It is ironic that in a context of a massive offensive of capital and increasing subsumption of labor, we are witnessing a new farewell to the working class.

The new farewell to the working class states (even if it does not support) the disappearance of protective labor regulation as inevitable, claiming that labor rights for "new" forms of work are inapplicable or impossible. Workers would be autonomous, entrepreneurs or a precariat without ties to a specific entity that would be liable for their rights. By assuming the inexorable trend of this process, both the old and the new farewell share a very problematic political outcome, according to which workers protected by the law are part of privileged groups. This understanding obscures the exploitation of labor and the real employers who benefit from the absence of legal obligation.

In Brazil, protective labor regulation has experienced a significant loss with the so-called Labor Reform (2017). Among hundreds of new rules that suppressed labor rights, the Labor Reform introduced a new article widening the concept of selfemployment (that may work for a single company with exclusivity), therefore, seeking to reduce the scope of workers suitable to labor law protection. For instance, "self-employed" drivers of cars and trucks grew $25.4 \%$ between the third semester of 2017 and the third semester of 2018 (PNAD).

There are signs of resistance among workers and institutions, as shown by decisions from Labor Courts in the UK and Brazil ${ }^{11}$ stating that UBER drivers are not self-employed, and inspections from the former Brazilian Ministry of Labor which concluded that couriers are employees of logistics companies ${ }^{12}$. Nev- ertheless, the number of formal car drivers hired as employees in Brazil decreased over 25\% after 2015, when UBER started to operate in the country. 17,530 drivers were dismissed after the Labor Reform up to February 2019, while total formal employment (whole labor market) has experienced a small increase.

A struggle over labor regulation is occurring. It is not a natural dynamic arising from economic factors or any technical order. UBER is a good example again. The underlying technology that allows the operation of the app already existed long before the company. What did not exist was the legal permission to gather personal data and promote transportation services without the legal hiring of workers. The "innovation" that matters here is mainly legal, resolved by politicians and lawyers, and not technological.

Despite the extremely unfavorable context to the protective regulation of labor, the outcome of this process is not inexorable. An essential part of the resistance against the flexible/precarious forms of hiring a workforce lies in a shift in the uncritical assimilation of business narrative, which needs to be critically rethought in regards to the arguments and designations about the organization of production and labor in current capitalism.

\section{Notes}

1 Of course, we assume that "capital strategies" mean a sort of complex historical-social process that includes how different wage-earning groups create and recreate forms of resistance, conflict and adaptation. Here, by focusing as indicated on how these strategies are formulated, the purpose is precisely to evaluate how these logics and practices affect the modalities of workers' struggle.

2 We are aware that the debate on social classes is broader than this and wage workers are marked by cleavages that lead, for instance, to the discussion about the difference between the working class (understood through the traditional concept of the proletariat) and the middle class (Cavalcante, 2012). However, the arguments presented here on the dynamics of the labor markets are located at a level of the problem that does not require such a discussion on the internal divisions of wage earners. 
3 See, for instance, Grozelier (1998), Bidet,Texier (1994), Silva; Rodrigues (2006).

4 Translations done by the authors.

5 The data used here were collected from our research done in 2015. As there are thousands of building sites in the country, we decided to analyze a broader sample of sites rather than the small number that are usually chosen in this kind of study. Thus, we defined a sample of 105 building sites in six different cities of the UK. To make the sample more representative, we chose some of the main cities in the UK, including the capitals of England, Wales and Scotland. By doing so, we were more likely to cover cities with a higher number of building sites. The cities were: London, Edinburgh, Cardiff, Leeds, Liverpool and Manchester. In each building site, we sought to analyze 17 variables of safe working conditions and five additional data about the employer and site information. In London, we tried to cover an area of the city as wide as possible. We also attempted to visit the building sites as many times as possible, checking the various stages of construction. Our method to cover different areas of the city without using the same criterion was to start from the tube stations. In each location, we selected the two first building sites nearest to the tube station. From April to December 2015, we inspected 74 building sites in 5 different zones of the city. We analyzed sites in south, east, west and north London.

6 This is also part of the research done in 2015, which included meetings and interviews with many agents engaged in the British labor market. Among them were managers, engineers, workers, unionists, activists and inspectors that enforce labor law in the UK. These moments were valuable in learning about the context on which is built the daily British world of work. They also helped in finding sources to think about and build indicators for the working conditions in the UK. We were able to hear different points of view, including those of workers, employers, managers, unionists and civil servants. Listening to the impressions, problems, perspectives and challenges experienced by them was a key factor to better understand and problematize the sources and data used here.

7 "The couriers are considered self-employed contractors despite working for one firm for about 50 hours a week. The often-long working day of a London courier involves weaving through the city's crowded and congested streets in the saddle covering 60 to 70 miles, to be paid normally between $£ 2$ and $£ 3$ per delivery, depending on distance" (BBC, 2016)
8 In one of the cases involving chicken catching in western Bahia, in 2013, the company stated that it "vehemently rejects any form of work and can be assimilated to the condition analogous to slavery" and that "the inspection was not carried out at Granja da Mauricea but in the property of an Integrated worker, a partner in the raising of chickens" (available at: http:// reporterbrasil.org.br/2013/05/mauricea-alimentosnota-de-esclarecimento/)

9 https://www.theguardian.com/business/2016/jul/20/ uber-driver-employment-tribunal-minimum-wage

10 Information obtained during interviews with UBER drivers are available online in Brazil: http://www.parceirosbr.com/politicas-e-regras/

11 See Process no 1000123-89.2017.5.02.0038.

12 See AUTO DE INFRAÇÃO No 21.359.221-5

\section{REFERENCES}

ABÍLIO, Ludmila. (2014), Sem maquiagem: o trabalho de um milhão de revendedoras de cosméticos. São Paulo, Boitempo.

ANTUNES, Ricardo. (1995), Adeus ao Trabalho?: Ensaios sobre as metamorfoses e a centralidade do mundo do trabalho. São Paulo, Cortez.

ARENDT, Hanna (1998 [1958]). The human condition. Chicago, The University of Chicago Press.

BETTELHEIM, Charles. (1976), A luta de classes na União Soviética, primeiro período (19171923). Rio de Janeiro, Paz e Terra.

BIDET, Jacques \& TEXIER, Jacques (1994). La Crise du Travail. Paris, PUF.

BRASIL. Ministério Público Do Trabalho. Ação civil pública, (2007). Available at: <actbr.org. br/uploads/.../188_MPTPRxsouzacruz_fumicultores.pdf>. Consulted in: 1/05/2011.

CNI. (2010), A indústria e o Brasil: uma agenda para crescer mais e melhor. Brasília, Confederação Nacional da Indústria.

CAVALCANTE, Sávio. (2012), Classe média e modo de produçáo capitalista: um estudo a partir do debate marxista. Tese de Doutorado (Sociologia). Universidade Estadual de Campinas, Campinas. COLEMAN, Clive. (2016), Bike couriers launch legal fight over workers' rights. BBC News. 
Available at: <http://www.bbc.com/news/uk36103978>. Consulted in: 10/05/2017

DARDOT, Pierre e LAVAL, Christian. (2016), $A$ nova razão do mundo: ensaio sobre a sociedade neoliberal. São Paulo, Boitempo.

FILGUEIRAS, Vitor. (2012), Estado e direito do trabalho no Brasil: regulação do emprego entre1988 e 2008. Tese de Doutoramento. FFCH/UFBA, Salvador.

FILGUEIRAS, Vitor. (2013), "Novas/Velhas formas de organização e exploração do trabalho: a produção "integrada" na agroindústria". Revista Mediaçôes, 18, 2: 230-245.

FILGUEIRAS, Vitor. (2016), "Regulação da terceirização e estratégias empresariais: o aprofundamento da lógica desse instrumento de gestão da força de trabalho". Cadernos do CEAS, 239: 742-770.

GLAA (2018). The Nature and Scale of Labor Exploitation across all Sectors within the United KingDOM. LONDON, Gangmasters and Labor Abuse Authority.

GORZ, Andre. (1983), Le chemins du Paradis, L'agonie du capital. Paris, Galilee.

GORZ, Andre. (1982), Farewell to the Working Class. London, Pluto Press.

GORZ, Andre. (1989), Critique of economic reason. London, Verso.

GROZELIER, Ann-Marie. (1988), Pour enfinir avec la fin du travail. Paris, Les Éditions de l'Atelier/Éditions Ouvrières.

ILO. (2015A), World employment and social outlook 2015: The changing nature of jobs / International Labor Office. Geneva, ILO.

ILO. (2015B), Panorama Laboral. International Labor Office. Geneva, ILO.

LOBEL, Fabrício. (2017), "Número de motoristas do Uber cresce dez vezes em um ano no Brasil". Folha de S. Paulo, 30 de outubro. (caderno Cotidiano).

POLANYI, Karl. (2000), A grande transformação: as origens de nossa época. Rio de Janeiro, Campus.

POULANTZAS, Nicos. (1977), Poder politico e classes sociais. São Paulo, Martins Fontes.

ROSENFIELD, Cinara. (2015), “Autoempreendedorismo: forma emergente de inserção social pelo trabalho". Revista Brasileira de Ciências Sociais, 30, 89: 115-128.

STADING, Guy. (2011), The Precariat: The New Dangerous Class. London, Bloomsbury Academic.

STADING, Guy. (2014), "Understanding the precariat through labor and work". Development and Change, The Hague (Haia), International Institute of Social Studies, 45, 50: 963-998.

STADING, Guy. (2016), "A Revolt Is Coming for Cloud Labor". Available in: <http://www. huffingtonpost.com/guy-standing/cloud-labor-revolt_b_8392452.html>. Consulted in: $10 / 05 / 2017$

O'CONNOR, Sarah. (2015), “'Bogus' self-employment deprives workers of their rights". Financial Times, August 18. Available in: <http:// www.ft.com/cms/s/0/e6231ad6-45a6-11e5af2f-4d6e0e5eda22.html\#axzz3k7YZIUhX> . Consulted in: 10/05/2017

OFFE, Claus. (1989), Trabalho \& Sociedade: problemas estruturais e perspectivas para o futuro da sociedade do trabalho. Rio de Janeiro, Tempo Brasileiro.

SEELY (2016), Antony. "Self-employment in the construction industry". Briefing paper, Number 000196, May 23.

SILVA, Josué \& RODRIGUES, Iram. (2006), André Gorz e seus críticos. São Paulo, Annablume. UK (2015), "Employment Status report". Office of tax simplification. March. 


\section{O QUE MUDOU: UM NOVO ADEUS À CLASSE TRABALHADORA?}

\section{Vitor Araújo Filgueiras e Sávio Machado Cavalcante}

Palavras-chave: Regulação do trabalho; Trabalho assalariado; Relaçóes de trabalho.

Este artigo problematiza a tese desenvolvida por diversos acadêmicos e instituiçôes segundo os quais as sociedades capitalistas passaram por uma mudança drástica na natureza das relaçóes de trabalho. Assume-se que mudanças sociais e econômicas no gerenciamento de trabalho e novas tecnologias teriam dissolvido formas tradicionais de emprego e a consequência seria um declínio do trabalho assalariado. Este "novo adeus à classe trabalhadora” contribui para a ideia que é impossível proteger trabalhadores através de regulaçôes públicas. Baseado em pesquisas empíricas, usando diversos estudos de caso e dados de mercados de trabalho no Brasil e no Reino Unido, nós argumentamos que "novas" formas de trabalho são predominantemente trabalho assalariado, a despeito dos esforços das empresas em disfarçar o conteúdo das relações de trabalho. Não negamos o surgimento de mudanças na gestão do trabalho pelas empresas, mas ressaltamos que isso inclui estratégias de dissimulação da relação salarial para reduzir as chances de limitar a exploração do trabalho.

\section{WHAT HAS CHANGED: A NEW FAREWELL TO THE WORKING CLASS?}

\section{Vitor Araújo Filgueiras and Sávio Machado Cavalcante}

Keywords: Work regulation; Wage labor; Work relationships.

This paper aims to discuss the thesis supported by several scholars and institutions according to which capitalist societies have been through a sharp shift in the nature of work relations. It assumes that social and economic changes in work management and new technologies would have dissolved traditional forms of employment, and the consequence would be a decline in wage labor. This new 'farewell to the working class' contributes to the idea that it is impossible to protect workers via public regulation. Based on empirical research using several case studies and data, especially from labor markets in Brazil and the United Kingdom, we argue that the "new" forms of work are predominantly wage labor, despite companies' efforts to disguise the content of employment relations. We do not deny the emergence of changes in labor management by companies. However, we point out that this includes strategies of dissimulation of the wage relationship to reduce chances of limiting labor exploitation.

\section{QU'EST-CE QUI A CHANGE : UN NOUVEL ADIEU A LA CLASSE OUVRIERE?}

\author{
Vitor Araújo Filgueiras et Sávio \\ Machado Cavalcante
}

Mots-clés: Régulation du travail; Travail salarié; Relation du travail.

Certains chercheurs et institutions pensent que les sociétés capitalistes ont connu un changement drastique au niveau de la nature des relations de travail. Les changements socio-économiques de la gestion du travail et les nouvelles technologies auraient ainsi dissous les formes d'emploi traditionnelles et entraîné un déclin du travail salarié. Ce " nouvel adieu à la classe ouvrière " laisse entendre qu'il est impossible de protéger les travailleurs à travers des régulations publiques. À partir de recherches empiriques, d'études de cas et de données sur les marchés de travail du Brésil et du Royaume-Uni, l'objectif de ce texte est de montrer que les "nouvelles " formes de travail sont essentiellement de l'ordre du travail salarié, et ce, en dépit des efforts des entreprises pour cacher le contenu des relations de travail. Si l'apparition de changements dans la gestion du travail par les entreprises se vérifie, nous pensons que cela inclut des stratégies de dissimulation de la relation salariale pour réduire les chances de limiter l'exploitation du travail. 